\title{
A unique combination of Alchornea cordifolia and Pterocarpus santalinoides in the management of multi-drug resistant diarrhoegenic bacterial infection.
}

\author{
Monday Obaji ${ }^{*}$, Ifeoma Bessie Enweani ${ }^{2}$, Angus Nnamdi Oli ${ }^{1}$ \\ ${ }^{1}$ Department of Pharmaceutical Microbiology and Biotechnology, Faculty of Pharmaceutical Sciences, Agulu, Nnamdi \\ Azikiwe University, Awka, Nigeria \\ ${ }^{2}$ Department of Medical Laboratory Science, FacultyHealth Science and Technology, Nnamdi Azikiwe University, \\ Nnewi, Nigeria
}

\begin{abstract}
Background: Traditionally, diarrhoea in our locality has often been managed using herbs. Multi-drugresistant organisms refer tomicrobes that areresistant to the effects of antimicrobial drugs to which they were previously susceptible at therapeutic range. Objectives: This study investigates the combined effects of Alchornea cordifolia and Pterocarpus santalinoides leaves extracts against selected multi-drug resistant diarrhoegenic bacteria.

Methods: Fresh plant seeds were collected from the plants, shade-dried, pulverized and extracted with methanol in a Soxhlet apparatus. Antibacterial activities of these plants were investigated using agarwell diffusion assay. The MIC and FIC of the extracts against test isolates were determined using agar well diffusion method and checkerboard assay respectively. The bactericidal effects of the extracts against the isolates were evaluated using Time-Kill Assay.

Results: MIC values of methanolic extracts against drug resistant strains of Salmonella typhi, Shigella dysenteriae, Escherichia coli and Staphylococcus aureusranges from $6.25 \mu \mathrm{g} / \mathrm{mL}$ to $12.5 \mu \mathrm{g} / \mathrm{mL}$. The combination of Alchornea cordifolia and Pterocarpus santalinoides extracts showed synergy at 8:2 and 4:6 combinations against $S$. aureus, Salmonella typhi and $E$. coli; at 7:3 combinations against $E$. coli; at 6:4 and 3:7 combinations against $S$. aureus, Salmonella typhi, $S$. dysenteriae; at 5:5 combinations against all the test isolates; at 2:8 combinations against $S$. aureus, $S$. dysenteriae and $E$. coli but additive against Salmonella organisms; at 1:9 combinations against $S$. aureus and Salmonella organism.

Conclusion: The methanol extracts of the plants at combinations 5:5 is synergistic against all the tested multi-drug resistant diarrhoegenic bacteria. Combination of Salmonellaand A. cordifolia showed potentials of synergism against the test isolates. The detection of synergy suggests presence of antibiotic resistance modifying compounds in those extracts.
\end{abstract}

Keywords: Alchornea cordifolia, Pterocarpus santalinoides, Diarrhoegenic bacteria, Antibiotic resistance, Polyherbal formulations. Accepted on January 06, 2020

\begin{abstract}
Abbreviations:
MIC: Minimum Inhibitory Concentration; FIC: Fractional Inhibitory Concentration; IZD: Inhibition Zone Diameter; SEM: Standard Error Mean

\section{Introduction}

Diarrhoea is a clinical condition that involves frequent passage of watery, loose or blood stained stool with attendance symptoms such as fatigue, malaise, vomiting, nausea and in some cases, severe complications such as dehydration and death especially in children and immunocompromised patients $[1,2]$.
\end{abstract}

Among other factors that cause diarrhoea, enteric pathogens such as bacteria (S. aureus, E. coli, Salmonella typhi., Shigellae spp.), viruses (Adenoviruses, Rotaviruses, Coronaviruses, Calciviruses, Astroviruses, Parvoviruses and Astroviruses), fungi (Candida albicans, C. tropicalis, C. krusei and Trichosporon spp) and parasites (Gardia lamblia, Cryptosporidium parvum and Entamoeba histolytica) have all been implicated in diarrhoea cases [2-4].

Like every other infectious diseases, antibiotics are used globally for the treatment of diarrhoea. However, due to the emergence and spread of resistant strains amongst clinically important pathogens, which have rendered most common and affordable antibiotics relatively ineffective, there is a need for herbal remedies that are both eco-friendly and contain 
chemical compounds that have not been associated with microbial resistance [5-7].

Throughout the history of mankind, herbal plants have been utilized across the globe by traditional healers to treat infectious and non-infectious diseases. The phytochemical diversity of these plants has been scientifically established as the bases for their antimicrobial propertie [8,9]. For instance, Alchornea cordifolia is widely utilised for the treatment of bacterial, fungal, protozoan infections and inflammatory diseases [10]. It is also taken as a blood purifier and for the treatment of other disease conditions such as epilepsy, anaemia, respiratory disease, prolonged menstruation, vaginitis, impotency and hemorrhage [11-13]. The fruits of Salmonella have been used to treat diarrhoea, prevent miscarriage and treat diseases of the skin in folk medicine [14-16]. Traditional healers also use leaf decoction for the treatment of toothache, gonorrhea and urethra discharge [16-19].

Pterocarpus santalinoides is a flowering plant commonly used as a vegetable for making soup and also utilized as a medicine by traditional medicine practitioners in Nigeria [20,21]. The root, stem, fruit and leaf concoctions are used for the treatment of many ailments, which include diarrhoea, candidiasis, malaria, cough, dysentery and diabetes etc. [21,22] The benefits of two or more herbal extracts are also being harnessed when the combined effect of those extracts are synergistic. In this study, checkerboard assay was used to determine the fractional inhibitory concentration of Alchornea cordifolia and Pterocarpus santalinoides seed extracts. The attempt was to explore possible synergistic effect between the two plant extracts against some selected bacterial isolates implicated in diarrhoea condition.

\section{Materials and Methods}

\section{Plant material and authentication}

The seeds of Alchornea cordifolia and Pterocarpus santalinoides were collected and authenticated by a taxonomist: Okeke Philomena N of the Department of Botany, Nnamdi Azikiwe University in Awka. Specimens were deposited in the departmental herbarium with the voucher numbers: Alchornea cordifolia - 78D and Pterocarpus santalinoides - 52A.

Test organisms: Diarrhoea causing bacteria, which include three gram negative (Escherichia coli, Salmonella typhi, and Shigellae dysenteriae) and one gram positive (Staphylococcus aureus) bacteria were obtained from Chukwuemeka Odumegwu Ojukwu Teaching Hospital Awka through diarrhoea sample stool.

\section{Media and Reagents}

Mueller Hinton Agar (Biomark Lab., India), Mannitol Salt Agar (Biomark Lab., India), Salmonella-Shigellae Agar (Biomark Lab., India), McConkey Agar (Oxoid Limited, UK), Nutrient Agar (Oxoid Limited, UK), Nutrient broth (LabM,
UK). Methanol (SIGMA-ALDRICH Inc., Germany), Dimethyl sulfoxide (DMSO) AR (JHD-Guangdong GuanghuaSci Tech Co. Ltd, China), distilled water, etc.

\section{Equipment and instruments}

Rotary Evaporator (Model RE 300, by Barloword Scientific Ltd, UK), Incubator (Genlab, UK), Autoclave (EQUITRON Partially Automatic Autoclave, by Medical Instrument Manufacturing Co., India) Hot Air Oven (Genlab, UK) Electronic weighing balance (Ohaus Corp., USA), Mechanical grinder, refrigerator, water bath, test tube, petri-dish etc.

\section{Preparation of the plant extracts}

Extraction was carried out using the method described by Aiyelaagbe and Osamudiamen with slight modifications $[23,24]$.The seeds of Alchornea cordifolia and Pterocarpus santalinoides were air-dried after washing with distilled water at room temperature, milled separately into fine powder with a mechanical grinder. Five hundred grams $(500 \mathrm{gm})$ of each of the powdered samples were macerated in 2.5 liters of methanol separately and were intermittently shaken for 24 hours. The mixtures were sieved using muslin cloth. They were further filtered with Whatman filter paper No. 1. The filtrates were concentrated at $45^{\circ} \mathrm{C}$ using rotary evaporator. They were further concentrated with water bath to $50 \%$. The crude extracts were stored in refrigerator at a temperature of $4-8^{\circ} \mathrm{C}$. Stock solutions of the methanolic extracts of the plants were prepared by dissolving $100 \mathrm{mg}$ of the extracts in $2 \mathrm{~mL}$ of DMSO respectively (to make $50 \mathrm{mg} / \mathrm{mL}$ ) and stored in screw capped tubes.

\section{Isolation and Identification of bacterial organism}

A loopful of the samples was inoculated on prepared nutrient agar and incubated at $37^{\circ} \mathrm{C}$ for 24 hours. The plates were examined under the microscope using gram staining technique. Pure cultures of the isolates were verified through biochemical testing. The following biochemical tests were carried for the purpose of identification of test isolates: catalase test, indole test, oxidase test, urease test, coagulase test, citrate test and motility test as described by Salami and Georgia [23].

\section{Determination of antibiotic susceptibility profile of test isolates}

Disc diffusion susceptibility test (modified Kirby-Bauer method) was employed as described by Cheesbrough [24]. The colonies were transferred from a 24 hours culture into a test tube and emulsified in a normal saline to obtain a homogenous suspension of the bacterial cells. The turbidity of the suspension was adjusted visually to that of McFarland 0.5 turbidity standard by addition of sterile physiological saline. A sterile swab stick was used to apply standardized inoculums on the surface of solidified Mueller Hinton agar. The antibiotic discs were aseptically placed on the inoculated plates using a sterilized forceps. Plates were incubated aerobically at $35^{\circ} \mathrm{C}-$ $37^{\circ} \mathrm{C}$ for 18 - 20 hours. The IZD around each disc was 
measured using a transparent rule. The procedure was carried out in triplicate.

\section{Primary screening of extracts for antibacterial activity}

Antimicrobial activity was assayed according to agar well diffusion method described by Ghamba et al. [25] Dilutions of $50,25,12.5,6.25,3.125$ and $1.5625 \mathrm{mg} / \mathrm{mL}$ were prepared from $100 \mathrm{mg} / \mathrm{mL}$ stock solutions of the two extracts. A $20 \mathrm{~mL}$ of molten Mueller Hinton agar was dispensed into sterile petri dishes and inoculated with $0.1 \mathrm{~mL}$ fresh cultures of test isolates at McFarland 0.5 concentration standard aseptically. Holes of 6 $\mathrm{mm}$ diameter were made in the agar plates using a sterile metal cork-borer. $60 \mu \mathrm{l}$ of the various dilutions of each extract and controls were dispensed in each hole under aseptic condition and incubated at $37^{\circ} \mathrm{C}$ for 24 hours and the zones of inhibition were measured. The procedure was carried out in triplicate.

\section{Combined antimicrobial activities of the plant extracts}

Checkerboard assay of antimicrobial combinations of the extracts against the test bacteria were evaluated using agar diffusion method described by Aiyegoro et al. [26]. The extracts were combined at concentration of $2 \times$ MIC of individual extracts. The concentrations of the extracts were prepared according to a continuous variation checkerboard technique using the ratio $0: 10,1: 9,2: 8,3: 7,4: 6,5: 5,6: 4,7: 3$, $8: 2,9: 1,10: 0$. The solutions of these extracts (Salmonella and A. cordifolia) combination were further diluted to 5 serial dilutions in two fold dilution process and the final concentrations were obtained. Their combined activity was assayed using agar well diffusion assay described above.

For each isolate, the FIC value for each extract was calculated using the formula:

FICA $=\frac{\text { Conc of } A \text { in } M I C A+B}{\text { MIC of } A \text { alone }}$

FIC $B=\frac{\text { Conc of } B \text { in } M I C A+B}{M I C \text { of } B \text { alone }}$

FIC index $=$ FICA + FICB. The interpretations of FIC index according to Aiyegoro et al. [26] is as follow: FIC index $<1.0$ means Synergism, $=1$ means additivity, $>1$ but less than 2 means indifference while $\geq 2$ means antagonism.

\section{Formulation of polyherbal extract}

Combination that showed synergistic effect against all the test isolates was formulated into polyherbal suspension using a formula described by Ghiware et al with little modification. $28100 \mathrm{mg}$ of the extracts (50 mg each for Alchornea cordifolia extract and Pterocarpus santalinoides extract) was mixed properly by triturating. 1 gm of anhydrous sorbitol was mixed with $25 \mathrm{ml}$ of glycerine and added to the extracts. Other excipients were added as shown in the Table 1 below. The two forms of suspension (S1 and S2) were prepared by adding microcrystalline cellulose in S1 suspension and sodium carboxyl methylcellulose in S2 suspension. The two forms of Suspension (S1 and S2) were evaluated for rate of settling. Sedimentation ratio was calculated using the formula below:

Sedimentation Ratio $=\mathrm{Vo} / \mathrm{Vu}$

Where $\mathrm{Vo}=$ Initial height of the sediment

$\mathrm{Vu}=$ Height of the sediment at a given time

Table 1. Formula of the polyherbal extracts suspension.

\begin{tabular}{llll}
\hline \multirow{2}{*}{ S.N } & Ingredients & \multicolumn{2}{l}{ Formulations } \\
\cline { 3 - 4 } & & $\mathrm{S} 2$ & $\mathrm{S3}$ \\
\hline 1 & Alchornia cordifolia & $50 \mathrm{mg}$ & $50 \mathrm{mg}$ \\
\hline 2 & Pterocarpus santalinoides & $50 \mathrm{mg}$ & $50 \mathrm{mg}$ \\
\hline 3 & Sorbitol & $1 \mathrm{gm}$ & $1 \mathrm{gm}$ \\
\hline 4 & Glycerine & $25 \mathrm{ml}$ & $25 \mathrm{ml}$ \\
\hline 5 & Soldium alginate & $1 \mathrm{gm}$ & $1 \mathrm{gm}$ \\
\hline 6 & Butylated hydroxyl toluene & $1 \mathrm{gm}$ & $1 \mathrm{gm}$ \\
\hline 7 & Propylene glycol & $15 \mathrm{ml}$ & $15 \mathrm{ml}$ \\
\hline 8 & Microcrystalline cellulose & $1 \mathrm{gm}$ & - \\
\hline 11 & Sodium benzoate & $1 \mathrm{gm}$ & $1 \mathrm{gm}$ \\
\hline & Sodium caboxyl methyl cellulose & - & $1 \mathrm{gm}$ \\
\hline
\end{tabular}

The combinations that showed synergism were formulated into polyhedral suspension. The slopes of the linear graph of the Sedimentation Ratios of the two suspensions are identical. The pooled slope equals 0.0042 . The $\mathrm{r}^{2}=0.9793$ and 0.9825 for $\mathrm{S} 1$ and $\mathrm{S} 2$ respectively. However, the intercepts are significantly different $(\mathrm{P}<0.0001)$.

\section{Data analysis}

Statistical analysis was performed using Graph pad Prism Software Version 5.10. All the results were expressed as Mean \pm SEM. Data were analyzed using linear regression. Pvalues $<0.05$ were considered statistically significant.

\section{Results}

The results (Table 2) of the MICs of the methanolic plant extracts under study showed that they were equally active against both gram positive and gram negative test isolates. Alchornea cordifolia and Pterocarpus santalinoides have MIC of $6.25 \mu \mathrm{g} / \mathrm{mL}$ respectively against Shigellae dysenteriae. Both plant extracts have MIC value of $12.5 \mu \mathrm{g} / \mathrm{mL}$ for $S$. aureus and E. coli. While Alchornea cordifolia has MIC of $6.25 \mu \mathrm{g} / \mathrm{mL}$ against S. typhi, Pterocarpus santalinoides has MIC of 12.5 $\mu \mathrm{g} / \mathrm{mL}$ against the same isolate. The effect of the combinations of the extracts against the isolates using checkerboard assay 
A unique combination of Alchornea cordifolia and Pterocarpus santalinoides in the management of multi-drug resistant diarrhoegenic bacterial infection

method showed synergism between Salmonella and $A$.

cordifolia .

Table 2. Percentage yields and MICs of the methanolic crude extract against the test isolates.

\begin{tabular}{|c|c|c|c|c|c|c|}
\hline & \multirow[t]{2}{*}{$\%$ Yield } & \multirow[t]{2}{*}{ Test isolates } & \multicolumn{4}{|c|}{ Minimum inhibitory concentration (in $\mathrm{mg} / \mathrm{mL}$ ) of the crude extracts on test isolates } \\
\hline & & & Staphylococcus aureus & Salmonella typhi & Shigellae dysenteriae & Escherichia coli \\
\hline \multirow[t]{2}{*}{ Plant Samples } & 6.9 & Alchornea cordifolia & 12.5 & 6.25 & 6.25 & 12.5 \\
\hline & 7.8 & Pterocarpus santalinoides & 12.5 & 12.5 & 6.25 & 12.5 \\
\hline
\end{tabular}

\section{Minimum inhibitory concentration (MIC) of the crude extracts on test isolates.}

Table 3 contains resistance profiles of the test isolates against some selected conventional antibiotics. The isolates used for this study showed multidrug resistant character. $S$. aureus was resistant to cefixime and co-amoxiclav but was highly susceptible to nitrofurantoin and ciprofloxacin with average inhibition zone diameters of 21 and 19.33 respectively. All the test isolates were resistant to ceftazidime except $S$. aureus with average IZD of 13.33. Besides ceftazidime, Salmonella typhi was resistant to cefuroxime, cefixime and co-amoxiclav.

Table 3. Antibiotic susceptibility profile of test organisms.

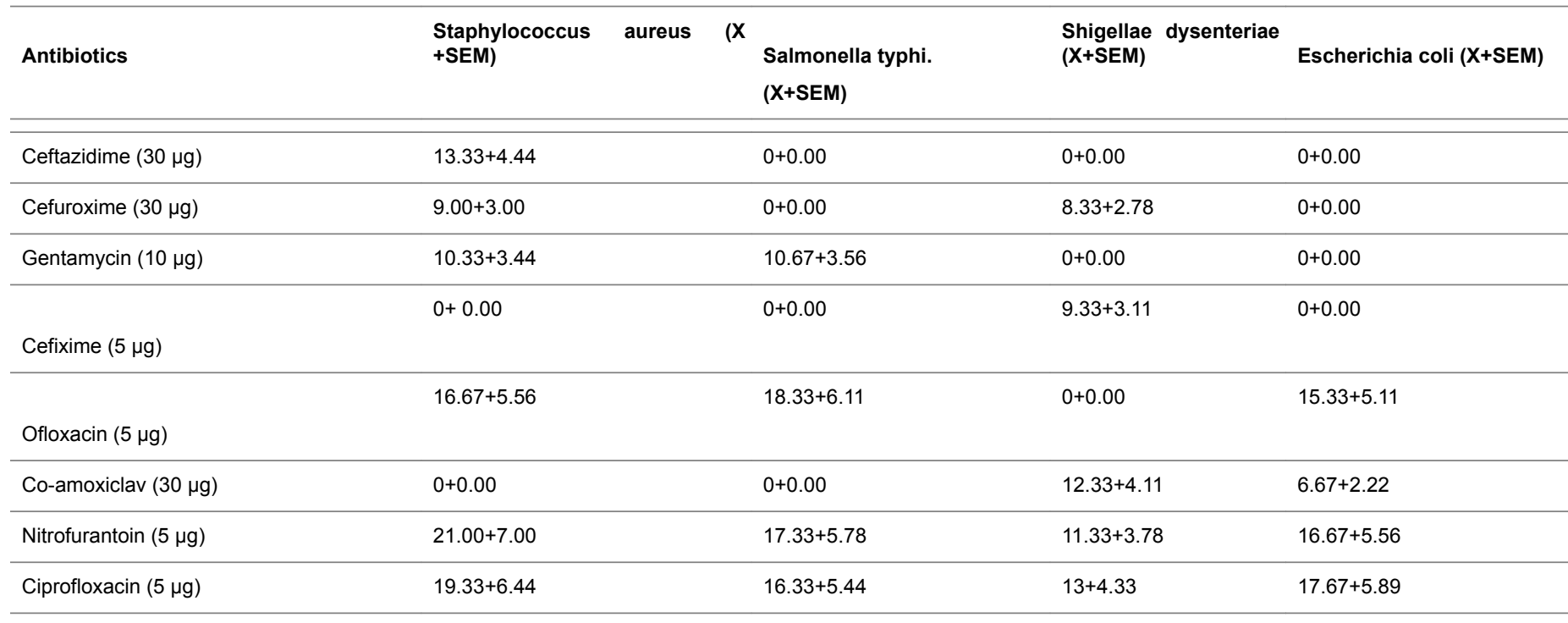

$\mathrm{X}=$ Mean; SEM=Standard Error of the Mean. The Mean Inhibition Zone Diameters $(\mathrm{mm})$ produced by various antibiotics against test isolates in the antibiotic susceptibility test.

In the evaluation of the bactericidal activity of the extracts against the test isolates, it was observed that after incubating the isolates with $1 / 2$ of the MIC for $2-4$ hours., there was increase of percentage viable cell count that ranged from $109.52 \%$ to $149 \%$ while between $6-8$ hours., the increase ranged between $137.56 \%$ to $228.18 \%$ with all the extracts prove ineffective against all the isolates as shown in Figure 1. When the MICs were doubled, that is, $2 \times$ MIC of each the extracts for the isolate and incubated with the bacterial isolates for $2-4$ hours., it resulted in percentage reduction of total viable count ranging from $86.67 \%$ to $37.5 \%$ and at $6-8$ hours., the reduction ranged from $42 \%$ to $2 \%$ with the extracts showing high activity against the isolates as shown in Tables 4-7. It can also be deduced that the killing ability of the extracts is both quantity and time dependent.

\section{Determination of the Bactericidal activities of crude extracts of various plant extracts on test isolates by Time-Kill Assay}

Table 4. Bactericidal activity of methanolic extracts of Pterocarpus santalinoides against test isolates $(1 / 2 \times$ MIC). 


\begin{tabular}{|c|c|c|c|c|c|c|}
\hline Test isolates & $(2 \times M I C) \mathrm{mg} / \mathrm{mL}$ & 0 hours & 2 hours & 4 hours & 6 hours & 8 hours \\
\hline S. aureus & 6.25 & 470 & 407 (86.67) & $321(68.33)$ & $105(25.71)$ & $29(6.19)$ \\
\hline S. aureus+ve control & & 980 & $1280(130.61)$ & $1410(143.88)$ & $1570(160.20)$ & 1950 (198.98) \\
\hline Salmonella typhi & 3.125 & 273 & $218(79.92)$ & $169(61.81)$ & $95(34.65)$ & $6(2.36)$ \\
\hline Salmonella typhi+ve control & & 830 & $920(110.84)$ & $1210(145.78)$ & $1490(179.52)$ & $1950(234.94)$ \\
\hline S. dysenteriae & 3.125 & 410 & $364(88.75)$ & $268(65.25)$ & $150(36.5)$ & $43(10.5)$ \\
\hline S. dysenteriae +ve control & & 950 & $1140(120)$ & $1380(145.26)$ & $1560(164.21)$ & $1600(168.42)$ \\
\hline E. coli & 6.25 & 230 & $135(58.7)$ & $71(30.87)$ & $23(10)$ & $5(2.17)$ \\
\hline E. coli+ve control & & 650 & 787 (121.08) & 979 (150.62) & $1126(173.23)$ & $1320(203.08)$ \\
\hline
\end{tabular}

Table 5. Bactericidal activity of methanolic extracts of Alchornea cordifolia against test isolates (1/2x MIC).

\section{The viable cell count with time (\% inhibition)}

\begin{tabular}{|c|c|c|c|c|c|c|}
\hline Test isolates & $\begin{array}{l}\text { Concentration } \\
(2 \times \mathrm{MIC}) \mathrm{mg} / \mathrm{mL}\end{array}$ & 0 hours & 2 hours & 4 hours & 6 hours. & 8 hours \\
\hline S. aureus & 6.25 & 470 & $520110.64)$ & $590(125.53)$ & $660(140.43)$ & $800(170.21)$ \\
\hline S. aureus+ve control & & 980 & $1280(130.61)$ & $1410(143.88)$ & $1570(160.20)$ & $1950(198.98)$ \\
\hline Salmonella typhi & 3.125 & 273 & $302(110.62)$ & $367(134.43)$ & $480(175.82)$ & 505 (184.98) \\
\hline Salmonella typhi+ve control & & 830 & $920(110.84)$ & $1210(145.78)$ & $1490(179.52)$ & $1950(234.94)$ \\
\hline S. dysenteriae & 3.125 & 410 & $472(115.12)$ & $543(132.44)$ & $564(137.56)$ & $620(151.22)$ \\
\hline S. dysenteriae +ve control & & 950 & $1140(120)$ & $1380(145.26)$ & $1560(164.21)$ & $1600(168.42)$ \\
\hline E. coli & 6.25 & 230 & $245(106.52)$ & $340(147.83)$ & $398(171.30)$ & 439 (190.87) \\
\hline E. colitve control & & 650 & $787(121.08)$ & 979 (150.62) & $1126(173.23)$ & $1320(203.08)$ \\
\hline
\end{tabular}

Table 6. Bactericidal activity of methanolic extracts of Pterocarpus santalinoides against test isolates (1/2x MIC)

$$
\text { The viable cell count with time (\% inhibition) }
$$

\begin{tabular}{|c|c|c|c|c|c|c|}
\hline \multirow[b]{2}{*}{ Test isolates } & \multirow{2}{*}{$\begin{array}{l}\text { Concentration } \\
(2 \times \mathrm{MIC}) \mathrm{mg} / \mathrm{mL}\end{array}$} & & \multirow[b]{2}{*}{2 hours } & \multirow[b]{2}{*}{4 hours } & \multirow[b]{2}{*}{6 hours } & \multirow[b]{2}{*}{8 hours } \\
\hline & & 0 hours & & & & \\
\hline S. aureus & 6.25 & 420 & $490(109.52)$ & $560(133.33)$ & $610(145.24)$ & $690(164.29)$ \\
\hline S. aureus+ve control & & 980 & $1280(130.61)$ & $1410(143.88)$ & $1570(160.20)$ & 1950 (198.98) \\
\hline Salmonella typhi & 3.125 & 220 & $289(131.36)$ & $340(154.55)$ & $402(182.73)$ & 447 (203.08) \\
\hline Salmonella typhi+ve control & & 830 & $920(110.84)$ & $1210(145.78)$ & $1490(179.52)$ & $1950(234.94)$ \\
\hline S. dysenteriae & 3.125 & 360 & $408(113.33)$ & $467(129.72)$ & $504(140)$ & $587(163.06)$ \\
\hline S. dysenteriae +ve control & & 950 & $1140(120)$ & $1380(145.26)$ & $1560(164.21)$ & $1600(168.42)$ \\
\hline E. coli & 6.25 & 200 & $284(142)$ & $336(168)$ & $359(180)$ & 398 (199) \\
\hline E. colitve control & & 650 & 787 (121.08) & 979 (150.62) & $1126(173.23)$ & $1320(203.08)$ \\
\hline
\end{tabular}

The fractional inhibitory concentrations of the combined crude extracts of the plants are shown in Table 8 . The combination of Salmonella and A. cordifolia showed (Table 8) more pronounced synergism against $S$. dysenteriae with FIC indices as low as ranging 0.44 , followed by the same combination against $S$. aureus, Salmonella typhi and E. coli.

Table 7. Bactericidal activity of methanolic extracts of Pterocarpus santalinoides against test isolates $(2 \times$ MIC). 
A unique combination of Alchornea cordifolia and Pterocarpus santalinoides in the management of multi-drug resistant diarrhoegenic bacterial infection

The viable cell count with time (\% inhibition)

\begin{tabular}{lllllll} 
Test isolates & $(\mathbf{2} \times \mathbf{M I C}) \mathbf{~ m g} / \mathbf{m L}$ & $\mathbf{0}$ hours & $\mathbf{2}$ hours & $\mathbf{4}$ hours & $\mathbf{6}$ hours & $\mathbf{8}$ hours \\
\hline S. aureus & 6.25 & 320 & $260(81.25)$ & $179(55.94)$ & $96(30)$ & $12(3.75)$ \\
\hline S. aureus+ve control & & 980 & $1280(130.61)$ & $1410(143.88)$ & $1570(160.20)$ & $1950(198.98)$ \\
\hline Salmonella typhi & 3.125 & 200 & $160(80)$ & $75(37.5)$ & $25(12.5)$ & $4(2)$ \\
\hline Salmonella typhi+ve control & & 830 & $920(110.84)$ & $1210(145.78)$ & $1490(179.52)$ & $1950(234.94)$ \\
\hline S. dysenteriae & 3.125 & 300 & $230(76.67)$ & $140(46.67)$ & $44(14.67)$ & $2(0.67)$ \\
\hline S. dysenteriae +ve control & & 950 & $1140(120)$ & $1380(145.26)$ & $1560(164.21)$ & $1600(168.42)$ \\
\hline E. coli & 6.25 & 200 & $166(83)$ & $93(46.5)$ & $27(13.5)$ & $8(4)$ \\
\hline E. coli+ve control & & 650 & $787(121.08)$ & $979(150.62)$ & $1126(173.23)$ & $1320(203.08)$
\end{tabular}

The fractional inhibitory concentrations of the combined crude extracts of the plants are shown in Table 8.The combination of Salmonella and A. cordifolia showed (Table 8) more pronounced synergism against $S$. dysenteriae with FIC indices as low as ranging 0.44 , followed by the same combination against $S$. aureus, Salmonella typhi and E. coli.

Table 8. Effects of the crude extracts of Alchornea cordifolia and Pterocarpus santalinoides against test isolates.

\begin{tabular}{|c|c|c|c|}
\hline AC : PS & Test Isolates & FIC & Interpretation of results \\
\hline \multirow{4}{*}{$10: 00$} & S. aureus & \multirow{4}{*}{-} & \multirow{4}{*}{-} \\
\hline & Salmonella typhi & & \\
\hline & S. dysenteriae & & \\
\hline & E. coli & & \\
\hline \multirow{4}{*}{ 9:01 } & S. aureus & 1.49 & Indifference>1 \\
\hline & Salmonella typhi & 1.57 & Indifference>1 \\
\hline & S. dysenteriae & 1.12 & Indifference >1 \\
\hline & E. coli & 1.43 & Indifference >1 \\
\hline \multirow{4}{*}{ 8:02 } & S. aureus & 0.88 & Synergism<1 \\
\hline & Salmonella typhi & 0.64 & Synergism<1 \\
\hline & S. dysenteriae & 1 & Indifference $>1$ \\
\hline & E. coli & 0.62 & Synergism<1 \\
\hline \multirow{4}{*}{$7: 03$} & S. aureus & 1.24 & Indifference $>1$ \\
\hline & Salmonella typhi & 1.53 & Indifference >1 \\
\hline & S. dysenteriae & 1.04 & Indifference >1 \\
\hline & E. coli & 0.74 & Synergism<1 \\
\hline \multirow[t]{4}{*}{$6: 04$} & S. aureus & 0.75 & Synergism<1 \\
\hline & Salmonella typhi & 0.48 & Synergism<1 \\
\hline & S. dysenteriae & 0.58 & Synergism<1 \\
\hline & E. coli & 1.04 & Indifference>1 \\
\hline
\end{tabular}

\begin{tabular}{|c|c|c|c|}
\hline \multirow{4}{*}{$5: 05$} & S. aureus & 0.88 & Synergism<1 \\
\hline & Salmonella typhi & 0.7 & Synergism<1 \\
\hline & S. dysenteriae & 0.44 & Synergism<1 \\
\hline & E. coli & 0.64 & Synergism<1 \\
\hline \multirow{4}{*}{$4: 06$} & S. aureus & 0.86 & Synergism<1 \\
\hline & Salmonella typhi & 0.92 & Synergism<1 \\
\hline & S. dysenteriae & 1.32 & Indifference $>1$ \\
\hline & E. coli & 0.46 & Synergism<1 \\
\hline \multirow{4}{*}{ 3:07 } & S. aureus & 0.91 & Synergism<1 \\
\hline & Salmonella typhi & 0.84 & Synergism<1 \\
\hline & S. dysenteriae & 0.65 & Synergism<1 \\
\hline & E. coli & 1.32 & Indifference $>1$ \\
\hline \multirow{4}{*}{$2: 08$} & S. aureus & 0.53 & Synergism<1 \\
\hline & Salmonella typhi & 1 & Additive $=1$ \\
\hline & S. dysenteriae & 0.53 & Synergism<1 \\
\hline & E. coli & 0.98 & Synergism<1 \\
\hline \multirow{4}{*}{ 1:09 } & S. aureus & 0.84 & Synergism<1 \\
\hline & Salmonella typhi & 0.81 & Synergism< 1 \\
\hline & S. dysenteriae & 1.53 & Indifference $>1$ \\
\hline & E. coli & 1.33 & Indifference $>1$ \\
\hline \multirow{4}{*}{$0: 10$} & S. aureus & & \\
\hline & Salmonella typhi & & 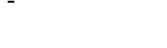 \\
\hline & S. dysenteriae & & \\
\hline & E. coli & & \\
\hline
\end{tabular}

AC=Methanolic Alchornea cordifolia extract while PS=Methanolic Pterocarpus santalinoides extract.

The two forms of suspension excellent sedimentation profiles as shown in Table 9. The final formulation has $\mathrm{pH}$ of 4.3 and 
specific gravity of $1.34 \mathrm{gm} / \mathrm{ml}$. The two possible forms of suspension; S1 and S2 were evaluated for sedimentation profile. S2 form of suspension showed sedimentation ratio of 2.1 after 270 minutes which is better than $\mathrm{S} 1$ form of suspension. All the two forms of suspension showed easily dispersible pattern.

Table 9. The sedimentation Rates of formulated suspensions.

\begin{tabular}{lllllll}
\hline & & & \multicolumn{3}{l}{$\mathbf{S 1}$} & \multicolumn{3}{l}{ S2 } \\
\cline { 5 - 7 } S.N. & $\begin{array}{l}\text { Time } \\
(\mathbf{m i n})\end{array}$ & $\begin{array}{l}\text { Ultimate } \\
\text { Vu (mL) }\end{array}$ & $\begin{array}{l}\text { Final } \\
\text { Height, } \\
\text { Vo } \\
(\mathbf{m L})\end{array}$ & $\begin{array}{l}\text { Final } \\
\text { Sedimentation } \\
\text { Ratio (Vu/Vo) } \\
\text { Vo } \\
\text { (mL) }\end{array}$ & $\begin{array}{l}\text { Sedimentation } \\
\text { Ratio (Vu/Vo) }\end{array}$ \\
\hline 1 & 30 & 100 & 79 & 1.27 & 88 & 1.14 \\
\hline 2 & 60 & 100 & 74 & 1.35 & 82 & 1.22 \\
\hline 3 & 90 & 100 & 65 & 1.54 & 71 & 1.41 \\
\hline 4 & 120 & 100 & 60 & 1.67 & 64 & 1.56 \\
\hline 5 & 150 & 100 & 56 & 1.79 & 60 & 1.67 \\
\hline 6 & 180 & 100 & 54 & 1.85 & 58 & 1.72 \\
\hline 7 & 210 & 100 & 51 & 1.96 & 56 & 1.79 \\
\hline 8 & 240 & 100 & 44 & 2.27 & 51 & 1.96 \\
\hline 9 & 270 & 100 & 43 & 2.33 & 47 & 2.13 \\
\hline
\end{tabular}

The suspension S1 which contains microcrystalline cellulose showed slightly better sedimentation rate compared to suspension S2 as shown in Figure 1.There is no significant difference in the Sedimentation Ratios of the two formulations (S1 and S2). The slopes of the linear graph of the Sedimentation Ratios of the two suspensions are identical (Figure 1). The differences between the slopes are not significant $(p=0.1277)$. The $r^{2}=0.9793$ and 0.9825 for $\mathrm{S} 1$ and $\mathrm{S} 2$ respectively. The pooled slope equals 0.0042 . However, the intercepts are significantly different. The differences between the intercepts are extremely significant $(\mathrm{p}<0.0001)$.

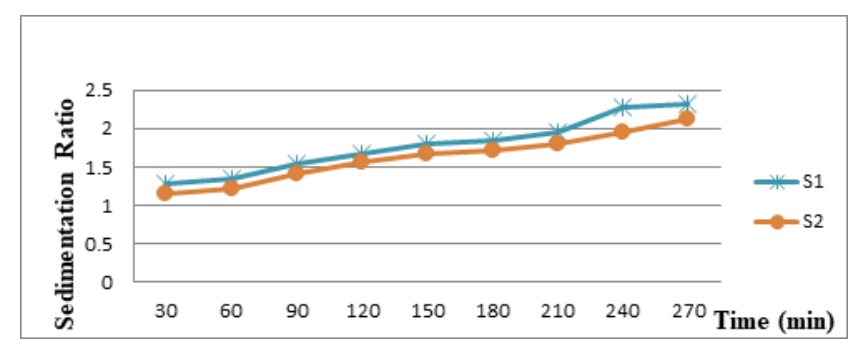

Figure 1. Comparative rate of sedimentation of the two forms of the polyherbal formulations.

\section{Discussion}

The major challenge evolving from treatment of infectious diseases is the ability of infective organisms to evade the lethal effect of antimicrobial agents. When a new molecule is advertised as effective agent against microorganisms of clinical importance, over time, the organism begins to evolve certain characteristics that help them circumvent the agent. Therefore, for an antibiotic to be considered effective against any bacterial species, the sensitivity of the organism to the antibiotic must have been established. The isolates used for this study showed multi-drug resistant character [27-30].

The methanolic extracts of Alchornea cordifolia and Pterocarpus santalinoides were subjected to antimicrobial challenge tests against multidrug resistant strains. The extracts showed significant activity against the test isolates. The antimicrobial activities of these plants in general can be attributed to the presence of important phytochemical compounds such as saponins, alkaloids, flavonoids, tannins, anthroquinines, steroids, terpenoids according to Ghamba et al. [25].

As the incidence of antimicrobial resistance remains an upward trend, plants extracts provide alternative to checkmating the menace. A candidate plant extract may have the ability to kill or inhibit the growth of a wide range of microorganisms. However, when two antimicrobial agents are combined, it does not always guarantee a higher efficacy against microbial cells. Therefore, before two agents are combined to achieve a better therapeutic effect, the synergistic interaction of those agents must be empirically established.

The methanolic extracts of Alchornea cordifolia and Pterocarpus santalinoides showed synergistic interaction against all the test isolates used in this study. Synergistic effects support the combination of Salmonella and A. cordifolia in the treatment of infections involving any of the test isolates instead of using them singly against the pathogens. Combinations with counter-productive effects had been documented. When there is a synergistic effect between two antimicrobial agents, it suggests that there is also different mode of actions of those agents according to Gutierez et al. [31] and the antibacterial activity of these plants extracts either singly or in combinations showed larger zone of inhibition at higher concentrations suggesting that antimicrobial properties of the extracts could be concentration dependent as suggested in earlier studies [32].

In the time kill assay, the extracts showed higher activity at higher concentration and over a longer period of exposure. Since the rate of cell death increases with time and volume of antimicrobial agents present, it can also be deduced that the killing ability of the extracts is time dependent.

\section{Conclusion}

The methanol extracts of the plants at combinations 5:5 is synergistic against all the tested multi-drug resistant diarrhoegenic bacteria. Combination of Salmonella and $A$. cordifolia showed potentials of synergism against the test isolates. The detection of synergy suggests presence of antibiotic resistance modifying compounds in those extracts. 


\section{References}

1. Asa S, Leila S, Daniel N, et al. Detection of major diarrheagenic bacterial pathogens by multiplexPCR panels. Microbiol Res. 2015; 172: 34-40.

2. Levine GA, Walson JL, Atlas HE, et al. Defining pediatric diarrhea in low-resource settings. J Pediat Inf Dis Soc. 2017; 6: 289-93.

3. Andrew S. Parasitic cause of prolonged diarrhoea in travelers. Diag Manag. 2010; 41: 782-86.

4. Verweij JJ, Blangé RA, Templeton K, et al. Simultaneous detection of Entamoeba histolytica, Giardia lamblia, and Cryptosporidium parvum in fecal samples by using multiplex real-time PCR. J Clin Microbiol. 2004; 42:1220-23.

5. Brook I, Gooch WM, Jeukins SG, et al. Medical management of acute bacterial sinusitis: Recommendations of a Clinical Advisory Committee of Pediatric and Adult Sinusitis. Ann Otol Rhinol Laryngol. 2006; 109: 1-19.

6. Chimezie CC, Eze PME, Oli AN, et al. The synergistic potentials of Platostomaafricanum and Psidiumguajava against some multi-drug resistant bacteria. EJMP. 2017; 18: $1-12$.

7. Sibanda T, Okoh AI. In vitro evaluation of the interactions between acetone extracts of Garcia kola seeds and some antibiotics. Afric J Biotech. 2008; 7: 1672-78.

8. Nwokorie CC, Nwachukwu NC, Ezeanokete CC, et al. The Phytochemical and Antimicrobial Analysis of Pterocarpus santalinoides Plants. Asian J Sci Technol. 2005; 6: 1411-1418.

9. Compean KL, Ynalvez RA. Antimicrobial activity of plant secondary metabolites: A review. Res J Med Plants. 2014; 8: 204-213.

10. Kone WM, Kamanzi AK, Traoré D, et al. Anthelmintic activity of medicinal plants used in northern Côte d'Ivoire against intestinal helminthiasis. Pharmaceut Biol. 2005; 43: $72-8$.

11. Iwu MM. Pharmacognostical Profile of Selected Medicinal Plants. African Med Plants, 2004; Nia R, Paper DH, Franz $\mathrm{G}$, et al. Anti-angiogenic, anti-inflammatory and antioxidant potential of an African recipe: Alchornea cordifolia seeds. Acta Horticult. 2005; 678: 91-96.

12. Mavar M, Brkic H, Marie D. In vivo anti-inflammatory activity of Alchornea cordifolia (Schumach. \&Thonn.) Mull.Arg. (Euphorbiaceae). J Ethnopharmacol. 2004; 92: 209-14.

13. Aggarwal BB, Prasad S, Reuter S, et al. Identification of novel anti-inflammatory agents from Ayurvedic medicine for prevention of chronic diseases: "reverse pharmacology" and "bedside to bench" approach. Current Drug Targets. 2011; 12: 1595-1653

14. Agbor GA, Leopold T, Jeanne NY. The antidiarrhoeal activity of Alchornea cordifolia leaf extract. Phytoth Res. 2004; 18: 873-876.

15. Okoye EL, Uba BO, Uhobo PC, et al. Evaluation of the antibacterial activity of methanol and chloroform extracts of Alchornea cordifolia leaves. J Scientific Res Rep. 2014; 3: 255-62.

16. Mann A, Gbate M, Nda UA. Medicinal and economic plants of Nupeland. Bida, Nigeria: Jube Evans Books and Publications. 2003.

17. Gatsing D, Nkeugouapi CFN, Nji-Nkah BF, et al. Antibacterial activity, bioavailability and acute toxicity evaluation of the leaf extract of Alchornea cordifolia (Euphorbiaceae). Int J of Pharmacol. 2010; 6: 173-82.

18. Erhenhi AH, Obadoni BO. Known medicinal and aphrodisiac plants of Urhonigbeforest reserve, Edo State, Nigeria. J Med Plants Stud. 2015; 3: 101-06

19. Ogbonna PC, Idumah MC. Phytochemical and mineral content of the leaves of four Nigeria Pterocarpus (2 ACQ) species. Int J App Sci Env Manag. 2008; 22: 1147.

20. Ezejiofor AN, Orish CN, Orisakwe OE. Effect of aqueous leaves extract of Costusafer Ker Gawl (Zingiberaceae) on the liver and kidney of male albino Wistar rat. Anc Scie Life. 2013; 33: 4-9.

21. Olowokudejo JD, Kadiri AB, Travih VA. An Ethnobotanical Survey of Herbal Markets and Medicinal Plants in Lagos State of Nigeria. Ethnobot Leaflets. 2008; 12: 851-65.

22. Aiyelaagbe OO, Osamudiamen PM. Phytochemical screening for active compounds in Mangifera indica leaves from Ibadan, Oyo State. Plant Sci Res. 2009; 2: 11-13.

23. Salami OO, Georgia CA. The assessment of the antimicrobial activities of Ocimumgratissimum (wild basil) and Vernoniaamygdalina (bitter leaf) on some enteric pathogen causing dysentry or diarrhoea in patients. Int $\mathrm{J}$ Eng Sci. 2013; 2: 83-96.

24. Cheesbrough M. District Laboratory Practice in Tropical Countries. Part 2. 2nd Edition. Cambri. Univer. Press, UK. 2006.

25. Ghamba PE, Balla H, Goje LJ. In-vitro antimicrobial activities of Vernoniaamygdalina on selected clinical isolates. Int J Cur Microbiol Appl Sci. 2014; 3: 1103-13.

26. Aiyegoro OA, Afolayan AJ, Okoh, AI. Synergistic interaction of Helichrysumpedunculatum leaf extracts with antibiotics against wound infection associated bacteria. Biol Res. 2009; 42: 327-38

27. Ghiware NB, Gattani SG, Chalikwar S. Design, Development and Evaluation of Oral Herbal Formulations of Piper nigrum and Nyctanthesarbortristis. Int J Pharm Tech Res. 2010; 2: 171-76.

28. Akpomie OO, Akpan I. Multidrug resistance among bacteria isolated from some foods sold in restaurants in Abraka, Nigeria Int J Microbiol Res Rev. 2003; 6: 97-102

29. Ujam NT, Oli AN, Ikegbunam MN, et al. Antimicrobial resistance evaluation of organisms isolated from liquid herbal products manufactured and marketed in South Eastern Nigeria. Br J Pharm Res. 2013; 3:548-62.

30. Oli AN, Obaji M, Enweani IB. Combinations of Alchornea cordifolia, Cassythafiliformis and Pterocarpus santalinoides in diarrhoegenic bacterial infections. BMC Res Notes. 2019; 12: 649. 
31. Gutierez J, Barry RC, Bourke P. The antimicrobial efficacy of plant essential oil combinations and interactions with food ingredients. Int J Food Microbiol. 2008; 124: 91-7.

32. Anyanwu MU, Okoye RC. Antimicrobial activity of Nigerian medicinal plants. J int Ethnopharmacol. 2017; 6: 240-59.

\section{"Correspondence to:}

Monday Obaji

Department of Pharmaceutical Microbiology and

Biotechnology

Nnamdi Azikiwe University

Awka, Nigeria

E-mail: obajiprince1@gmail.com 